Arq. Bras. Med. Vet. Zootec., v69, n.1, p.117-122, 2017

\title{
Staphylococcus sciuri associated to subcutaneous abscess and dermatitis in ICR mouse
}

\author{
[Staphylococcus sciuri associado a abcesso subcutâneo e dermatite em ratos] \\ K. Kengkoom, S. Ampawong* \\ Mahidol University Salaya - Phuttamonthon - Nakorn Pathom, Thailand
}

\begin{abstract}
Subcutaneous mass was found in ICR mouse during daily health observation in the breeding colony of the National Laboratory Animal Center, Mahidol University, Thailand. The animal was subsequently culled and humanely sacrificed due to the institutional preventive medicine policy. Microbiological and histopathological studies were performed for definitive diagnosis. The results described that the case was subcutaneous abscess and chronic dermatitis in association with Staphylococcus sciuri infection without epizootic and mortality. This was determined as the first reported case in Thailand occurring in mouse. Reproductive stress and abrasion skin wound may be the predisposing factors. Although pathogenic staphylococci in laboratory animals are limited to S. aureus and S. xylosus, S. sciuri opportunistic properties, natural history, and heterogeneity should not be forgotten.
\end{abstract}

Keywords: dermatitis, ICR mouse, Staphylococcus sciuri, subcutaneous abscess

\section{RESUMO}

Uma massa subcutânea foi encontrada em um rato ICR durante uma observação diária de saúde na colônia reprodutora do Laboratório do Centro Animal Nacional, na Universidade de Mahidol, Tailândia. O animal foi selecionado e humanamente sacrificado devido à política institucional de medicina preventiva. Estudos microbiológicos e histopatológicos foram realizados para um diagnóstico definitivo. Os resultados descrevem que o caso foi um abcesso subcutâneo e dermatite crônica associado com infecção por Staphylococcus sciuri sem epizootia e mortalidade. Este foi determinado como o primeiro caso relatado em ratos na Tailândia. Estresse reprodutivo e ferida abrasiva na pele podem ser os fatores de predisposição. Apesar de staphylococci patogênicos em animais de laboratório serem limitados a S. aureus E S. xylosus, as propriedades oportunistas, história natural e heterogeneidade do $S$. sciuri não devem ser esquecidos.

Palavras chave: dermatite, rato ICR, Staphylococcus sciuri, abcesso subcutaneo

\section{INTRODUCTION}

Staphylococcus aureus, S. intermedius, and $S$. hyicus are known as the pathogenic coagulasepositive staphylococci (CoPS) which are pyogenic and associated with abscess formation or suppuration. Since the coagulase positive has been correlated well with pathogenicity, two commonly isolated coagulase-negative staphylococci (CoNS), S. epidermidis and $S$. saprophyticus, occur as commensalism and habit in the environment (Quinn et al., 1994). S. sciuri is also categorized as CoNS. Members of its subspecies, sciuri, rodentium, lentus, vitulinus, are principally animal species (farm animals, pets, and wild rodents) and may colonize humans (Kloos et al., 1976; Hauschild and Schwarz, 2003).

Moreover S. sciuri has been associated with serious infections in humans such as endocarditis, peritonitis, septic shock, and wound infections (Hedin and Widerstrom, 1998; Stepanovic et al., 2000; Wallet et al., 2000; Horii et al., 2001), however the incidence is merely rare (Li et al., 2011b). Similar to the incidence in the laboratory animal species, nevertheless, the infection with $S$. sciuri commonly plays commensal of oral cavity in rodent species e.g.

Recebido em 1 de julho de 2015

Aceito em 11 de fevereiro de 2016

* Autor para correspondência (corresponding author)

E-mail: sumate.aum@mahidol.ac.th 
$\mathrm{BALB} / \mathrm{c}$ mice, $\mathrm{C} 57 \mathrm{BL} / 6 \mathrm{~N}$ mice, and $\mathrm{C} 3 \mathrm{H} / \mathrm{HeN}$ mice (Trudel et al., 1986; Nakano, 1989; Hauschild and Schwarz, 2003). Phenotyping and genotyping analysis of $S$. sciuri in free-living rodents exhibited a highly heterogeneous population such as subsp. sciuri N960546, subsp. sciuri PCM2424, and subsp. carnaticus N960509 (Hauschild and Schwarz, 2003), all of these are concerned as nonpathogenic strain. In the present study, this is the first reported case of S. sciuri infection in ICR mouse in Thailand, associated to subcutaneous abscess and dermatitis without other clinical manifestations or its epizootics.

\section{RESULTS}

The female ICR mouse, after the $1^{\text {st }}$ post weaning, was found with a subcutaneous mass on the lateral upper right side of the leg at 16 weeks of age. This case was detected during daily health observation by technical caring without increasing morbidity and mortality. This ICR mouse colony was categorized as monitored animal and maintained in Low Barrier System with Heating, Ventilating, and Air Conditioning (HVAC) system. Their microbiological status was characterized by specific pathogen list which indicated that $77 \%(154 / 200)$ prevalence of Staphylococcus aureus were endemic without other detailed pathogens (Table 1.). All animal procedures performed were in accordance with regulations and were approved by an Institutional Animal Care and Use Committee of National Laboratory Animal Center, Mahidol University.

Table 1. Microbiological status of ICR mouse colony maintained in Low Barrier with HVAC system

\begin{tabular}{|c|c|c|c|c|c|}
\hline Test & Pathogens & Result & Test & Pathogens & Result \\
\hline \multirow{7}{*}{ 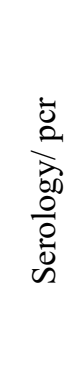 } & Mouse rotavirus & $0 / 30$ & \multirow{6}{*}{ 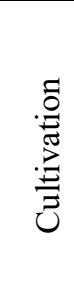 } & Mycoplasma pulmonis & $0 / 200$ \\
\hline & Lcmv & $0 / 10$ & & Pasteurella pneumotropica & $0 / 200$ \\
\hline & Hantavirus & $0 / 10$ & & Streptococcus pneumoniae & $0 / 200$ \\
\hline & Gdv ii strain & $0 / 30$ & & Pseudomonas aeruginosa & $0 / 200$ \\
\hline & Reovirus type 3 & $0 / 10$ & & Staphylococcus aureus & $154 / 200$ \\
\hline & Clostidium piliforme & $0 / 7$ & & Dermatophyte & $0 / 200$ \\
\hline & Mycoplasma pulmonis & $0 / 7$ & \multirow{4}{*}{$\begin{array}{l}\text { ते } \\
0 \\
0 \\
0 \\
0 \\
.0 \\
\sum\end{array}$} & Giardia muris & $0 / 200$ \\
\hline \multirow{3}{*}{ 葛 } & Salmonella spp. & $0 / 200$ & & Spironucleus muris & $0 / 200$ \\
\hline & Citrobacter rodentium & $0 / 200$ & & Syphacia spp. & $0 / 200$ \\
\hline & Corynebacterium kutscheri & $0 / 200$ & & Ectoparasites & $0 / 200$ \\
\hline
\end{tabular}

The test result values are number of animals tested positive over number of animals tested annually. Lcmv; lymphocytic choriomeningitis virus, gdv ii strain; mouse encephalomyelitis virus, pcr; polymerase chain reaction.

The animal was subsequently culled and humanely sacrificed with overdose of carbon dioxide inhalation due to the Institutional preventive medicine policy. At necropsy the mouse was $42.66 \mathrm{~g}$ body weight. No other abnormal gross appearances except the subcutaneous mass were exhibited. The mass contour was oval shape with $1 \times 1 \times 0.5 \mathrm{~cm}$ in size (Fig. 1.), firm elasticity wall, and filled with purulent exudates. The exudates were cultivated and isolated by conventional methods using DHL agar and sheep blood agar with 24 hours incubation at $37^{\circ} \mathrm{C}$ (Kloos et al., 1976). Commercial identification kits, API Staph (bioMerieux, Marcy-l'Etoile, France), was used for species identification. The mass was trimmed, fixed, embedded in paraffin, sectioned at $5 \mu \mathrm{m}$, and stained with hematoxylin and eosin (H\&E). Moreover, ten post weaning mice, 3 weeks old, in the same colony were randomly sampled for microbiological surveillance. The oral and caecal swab were also cultivated and isolated with the method mentioned above. 


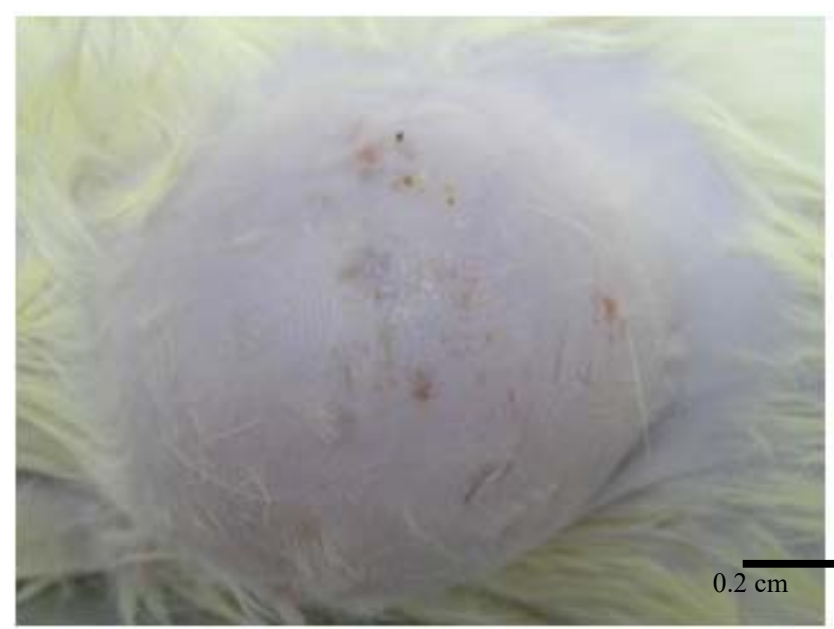

Figure 1. Gross appearance of the mass. After hair shaving, the single-oval shaped mass was obviously seen characterized by a cutaneous swelling with contained fluid inside.

The results showed that bacterial identification of the case based on the described methods was identified as $S$. sciuri which was gram positive cocci, $0.7-1.2 \mu \mathrm{m}$ diameter (Figure 2A.), with circular yellowish-grey colony morphology, nonmotile, non-sporing, occurring singly and forming pairs to tetrad, oxidase negative, catalase positive, and coagulase negative. The biochemical trait of the isolate was described in Table 2. The isolated trait was characterized by positive D-glucose, D-fructose, D-mannose, Dmaltose, D-lactose, D-trehalose, D-manitol, potassium nitrate, $\beta$-naphthyl phosphate, sodium pyruvate, D-saccharose, and $\mathrm{N}$-acetylglucosamine which probably closed to subsp. sciuri or rodentium. Histological findings showed chronic dermatitis indicated by mononuclear cells, mainly lymphocytes and macrophages, infiltration to the dermal area. Moderate regular lamellar parakeratotic hyperkeratosis, discrete ballooning degeneration, and subcutaneous abscess formation were also seen (Figure 2B-F.). A fibrous capsule was eventually formed around an abscess. Pus was composed of the debris of dead leukocytes, calcification, abundant living and dead bacteria, fibrin strand, bright eosinophilic amorphous material, and surrounded by intact phagocytic cells. Post weaning microbiological surveillance showed that all of the specimens from both oral cavity and caecum are $S$. aureus colonization in range $91.7-97.8 \%$ identity.

Arq. Bras. Med. Vet. Zootec., v69, n.1, p.117-122, 2017

\section{DISCUSSION AND CONCLUSIONS}

Staphylococcal infections of laboratory rodents seem to be distributed worldwide with highly variable prevalence influenced by predisposing factors such as stress of pregnancy, shipment, dietary deficiencies, concurrent infection, and experimental procedures (Waggie et al., 1994). Moreover, the other factors that are associated to staphylococcosis are immune status, competing bacteria imbalance, nutritional deficiencies, breaks in the integument related to trichotillomania (as in B6 mice), ectoparasitic infestations, and fighting injuries (Barthold and Percy, 2007). In this case reported here, perhaps the commercial reproductive system would have been the major stressor accompanied by abrasion skin wound causing $S$. sciuri infection and leading to chronic dermatitis, abscess, and other related skin lesions.

The occurrence of abscessation from staphylococcal infection in mice is normally found in preputial and lacrimal glands, mainly caused by $S$. aureus, S. xylosus, and $S$. epidermidis (Barthold and Percy, 2007). Unfortunately, little is known about the pathology and epidermiology of $S$. sciuri infection in laboratory animals. Few reports indicated the commensal property of S. sciuri in saliva, tongue, teeth, and oral mucosa without genotypic studies (Trudel et al., 1986; Nakano, 1989). Interestingly, the study of staphylococcal infection on the skin from laboratory mice reported that the incidence of $S$. xylosus, $S$. 
sciuri, and S. aureus was $69.6 \%, 43.5 \%$, and $39.1 \%$, respectively (Nagase et al., 2002). Obviously, although $S$. sciuri was normally isolated from both oral (Trudel et al., 1986; Nakano, 1989; Hauschild and Schwarz, 2003) and normal skin (Nagase et al., 2002) from laboratory mice, the present case demonstrated its individually opportunistic pathogen property. However, the disease natural history of S. sciuri, claiming it as an opportunistic pathogen is still controversial with a wide spectrum of predisposed factors including host, strain, and environmental factors (Hedin and Widerstrom, 1998). Recently, S. sciuri strain HBXX06 (carry exfoliate toxin: ExhC) was reported as highly pathogenic when inoculated in piglets and $\mathrm{BALB} / \mathrm{c}$ mice and caused fatal exudative epidermitis (Chen et al., 2007). This toxin induces severe skin lesion in new borne mice, especially blisters, exfoliation, and tissue necrosis (Li et al., 2011a; Li et al., 2011b). These may emphasize a highly heterogeneous $S$. sciuri, the prevalence study of genotyping among subgroup will be required to elucidate the understanding of its natural history.
The strategies used to control or eliminate emerging and reemerging pathogens, as called outbreak response, especially opportunistic microorganisms from the laboratory animal colony depend on these organisms' risk to institutional programs (Besselsen et al., 2008). The strategies include consideration of the colony requirements, numbers of animals at risk, and available facility resources together with the selective control measures' cost, complexity, and probability of success (Hedin and Widerstrom, 1998). The opportunistic pathogens were denoted an organism capable of causing disease only in a host whose resistance is lowered (Waggie et al., 1994; Hedin and Widerstrom, 1998; Besselsen et al., 2008). They do not affect research and breeding performance uniformly. Although relatively few opportunistic organisms have been implicated in consistently causing clinical disease or interfering with research following infection (Baker, 2003), such pathogenic staphylococci in laboratory mouse are limited to S. aureus and S. xylosus (Barthold and Percy, 2007), the pathogenic strain of S. sciuri should be reminded.

Table 2. Biochemical trait of the isolate compared to different strains of S. sciuri

\begin{tabular}{|c|c|c|c|c|c|c|}
\hline \multirow[b]{2}{*}{ Trait } & \multirow[b]{2}{*}{ Isolate } & \multicolumn{5}{|c|}{ Indicated trait of difference strains of S. sciuri } \\
\hline & & HBXX06 & $\begin{array}{l}\text { subsp. } \\
\text { sciuri }\end{array}$ & $\begin{array}{l}\text { subsp. } \\
\text { rodentium }\end{array}$ & $\begin{array}{l}\text { subsp. } \\
\text { lentus }\end{array}$ & $\begin{array}{l}\text { subsp. } \\
\text { vitulinus }\end{array}$ \\
\hline D-glucose & + & na & $+^{\mathrm{b}, \mathrm{d}}$ & $+{ }^{\mathrm{d}}$ & $++^{\mathrm{b}, \mathrm{d}}$ & $+^{\mathrm{d}}$ \\
\hline D-fructose & + & $+^{\mathrm{a}}$ & $0^{\mathrm{b}} /+^{\mathrm{d}}$ & $+{ }^{\mathrm{d}}$ & $0^{\mathrm{b}} /+^{\mathrm{d}}$ & $+^{\mathrm{d}}$ \\
\hline D-mannose & + & $t^{\mathrm{a}}$ & $+{ }^{b, d}$ & $++^{\mathrm{d}}$ & $+{ }^{\mathrm{d}}$ & $0^{\mathrm{d}}$ \\
\hline D-maltose & + & $t^{\mathrm{a}}$ & $+^{\mathrm{b}, \mathrm{c}, \mathrm{d}}$ & $+{ }^{\mathrm{d}}$ & $+{ }^{\mathrm{d}}$ & $0^{\mathrm{d}}$ \\
\hline D-lactose & + & $+^{\mathrm{a}}$ & $0 \% /+^{\mathrm{c}} / \pm^{\mathrm{d}}$ & $\pm^{\mathrm{d}}$ & $+{ }^{\mathrm{d}}$ & $0^{\mathrm{d}}$ \\
\hline D-trehalose & + & $+^{\mathrm{a}}$ & $++^{\mathrm{b}, \mathrm{c}, \mathrm{d}}$ & $+{ }^{\mathrm{d}}$ & $+^{\mathrm{b}, \mathrm{d}}$ & $0^{\mathrm{d}}$ \\
\hline D-manitol & + & $+^{\mathrm{a}}$ & $+^{\mathrm{b}, \mathrm{c}, \mathrm{d}}$ & $+^{\mathrm{d}}$ & $+^{\mathrm{b}, \mathrm{d}}$ & $\pm^{\mathrm{d}}$ \\
\hline Xylitol & 0 & $0^{\mathrm{a}}$ & $++^{\mathrm{b}, \mathrm{c}} / 0^{\mathrm{d}}$ & $0^{\mathrm{d}}$ & $0^{\mathrm{d}}$ & $0^{\mathrm{d}}$ \\
\hline D-melibiose & 0 & $0^{\mathrm{a}}$ & $++^{\mathrm{b}, \mathrm{c}} / 0^{\mathrm{d}}$ & $0^{\mathrm{d}}$ & $++^{\mathrm{b}, \mathrm{d}}$ & $0^{\mathrm{d}}$ \\
\hline Potassium nitrate & + & $+^{\mathrm{a}}$ & $+^{\mathrm{b}, \mathrm{c}, \mathrm{d}}$ & $+{ }^{\mathrm{d}}$ & $+^{\mathrm{b}, \mathrm{d}}$ & $+^{\mathrm{d}}$ \\
\hline${ }^{\beta}$-naphthyl phosphate & + & na & na & na & na & na \\
\hline Sodium pyruvate & + & $0^{\mathrm{a}}$ & na & na & na & na \\
\hline D-raffinose & 0 & na & $++^{\mathrm{b}, \mathrm{c}} / 0^{\mathrm{d}}$ & $0^{\mathrm{d}}$ & $+{ }^{\mathrm{d}}$ & $0^{\mathrm{d}}$ \\
\hline D-xylose & 0 & $+^{\mathrm{a}}$ & $++^{\mathrm{b}, \mathrm{c}} / 0^{\mathrm{d}}$ & $0^{\mathrm{d}}$ & $+{ }^{\mathrm{d}}$ & $+{ }^{\mathrm{d}}$ \\
\hline D-saccharose & + & na & $+^{\mathrm{d}}$ & $++^{\mathrm{d}}$ & $+^{\mathrm{d}}$ & $t^{\mathrm{d}}$ \\
\hline 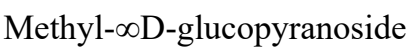 & 0 & na & na & na & na & na \\
\hline $\mathrm{N}$-acetyl-glucosamine & + & $+^{\mathrm{a}}$ & $+^{\mathrm{c}, \mathrm{d}}$ & $++^{\mathrm{d}}$ & $+{ }^{\mathrm{d}}$ & $0^{\mathrm{d}}$ \\
\hline L-arginine & 0 & na & na & na & na & na \\
\hline Urea & 0 & $0^{\mathrm{a}}$ & na & na & na & na \\
\hline B-hemolytic & 0 & $0^{\mathrm{a}}$ & $0^{b, c, d}$ & $0^{\mathrm{d}}$ & $0^{\mathrm{d}}$ & $0^{\mathrm{d}}$ \\
\hline
\end{tabular}

Previous citation of biochemical trait of differences in S. sciuri subspecies: a; (Chen et al., 2007), b; (Kloos et al., 1976), c; (Hauschild and Schwarz, 2003), d; (Stepanovic et al., 2000), +; positive, 0; negative, \pm ; 50\% positive, and na; not available. 

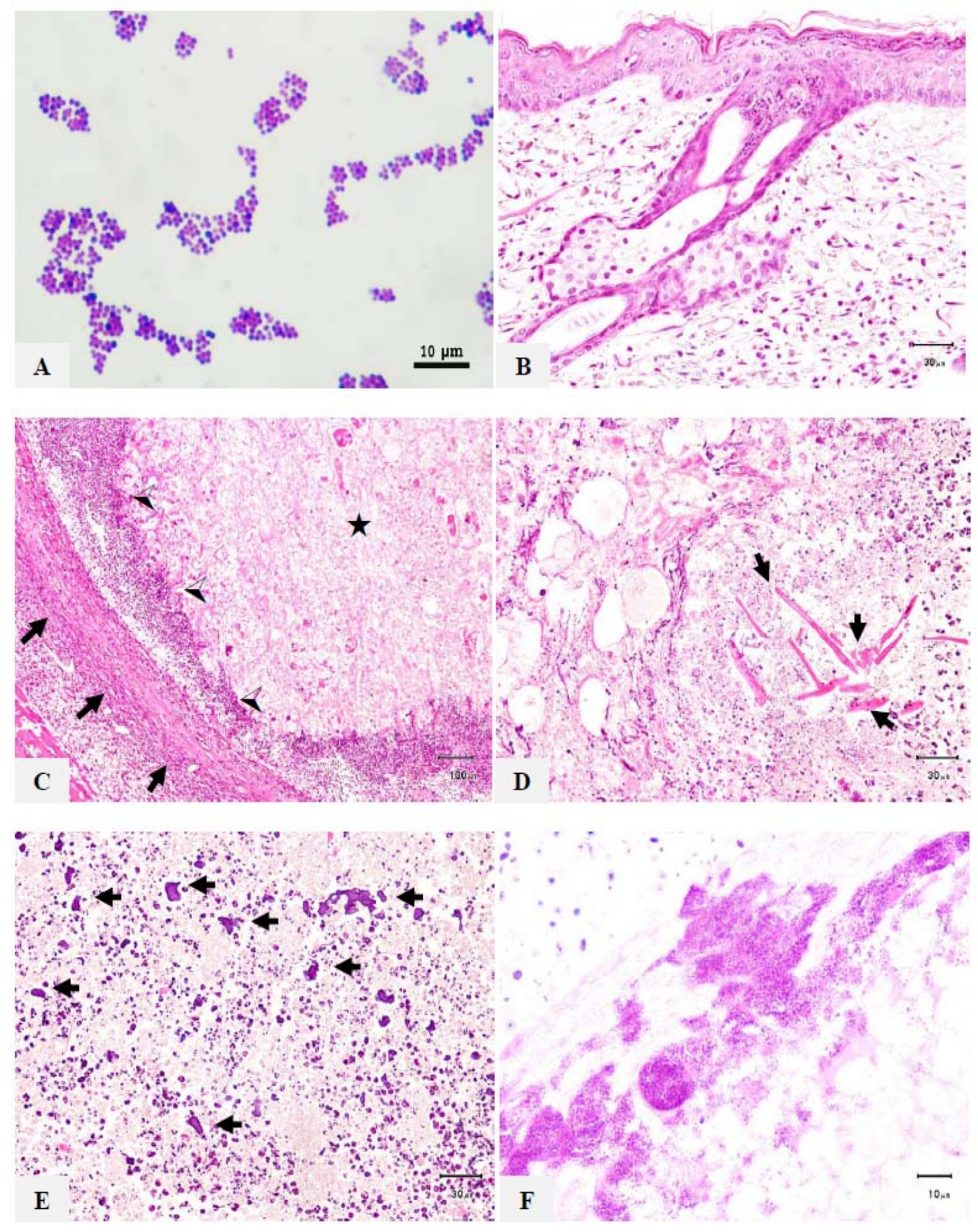

Figure 2 Microscopic studies of the mass. A: Gram's staining of the S. sciuri isolated. B: Dermatitis exhibited mixed inflammation with predominant polymorphonuclear cells. C-F: Subcutaneous abscess formation, characterized by necrotizing suppurative inflammation with a central core composed of the tissue debris $(\mathrm{C}-\star)$, leukocytes $(\mathrm{C}-\varangle)$, bright eosinophilic amorphous material (D-arrow), calcification (E, arrow), and abundant bacteria (F, bluish cocci shaped) surrounded by a fibrous capsule (C, arrow). 


\section{ACKNOWLEDGEMENTS}

This work was supported by the National Laboratory Animal Center and Faculty of Tropical Medicine, Mahidol University, Thailand.

\section{REFERENCES}

BAKER, D.G. Natural pathogens of laboratory animals: their effects on research. Washington: American Society for Microbiology Press, 2003. $385 \mathrm{p}$.

BARTHOLD, S.W.; PERCY, D.H. Pathology of laboratory rodents and rabbits. Copenhagen: Blackwell Publishing, 2007. 325p.

BESSELSEN， D.G.; FRANKLIN， C.L.; LIVINGSTON, R.S.; RILEY, L.K. Lurking in the shadows: emerging rodent infectious diseases. ILAR J., v.49, p.277-290, 2008.

CHEN, S.; WANG, Y.; CHEN, F. et al. A highly pathogenic strain of Staphylococcus sciuri caused fatal exudative epidermitis in piglets. PloS one 2, p.e147, 2007.

HAUSCHILD, T.; SCHWARZ, S. Differentiation of Staphylococcus sciuri strains isolated from free-living rodents and insectivores. J. Vet. Med. B, Infect. Dis. Vet. Public Health, v.50, p.241-246, 2003.

HEDIN, G.; WIDERSTROM, M. Endocarditis due to Staphylococcus sciuri. Eur. J. Clin. Microbiol. Infect. Dis., v.17, p.673-675, 1998.

HORII, T.; SUZUKI, Y.; KIMURA, T. et al. Intravenous catheter-related septic shock caused by Staphylococcus sciuri and Escherichia vulneris. Scand. J. Infect. Dis., v.33, p.930-932, 2001.

KLOOS, W.E.; SCHLEIFER, K.H.; SMITH, R.F. Characterization of Staphylococcus sciuri sp.nov. and its subspecies. Int. J. Syst. Evol. Microbiol., v.26, p.22-37, 1976.
LI, H.; LI, X.; LU, Y. et al. Staphylococcus sciuri exfoliative toxin $\mathrm{C}$ is a dimer that modulates macrophage functions. Can. J. Microbiol., v.57, p.722-729, 2011 a.

LI, H.; WANG, Y.; DING, L.; ZHENG, S.J. Staphylococcus sciuri exfoliative toxin $\mathrm{C}$ (ExhC) is a necrosis-inducer for mammalian cells. PloS one 6, p.e23145, $2011 \mathrm{~b}$.

NAGASE, N.; SASAKI, A.; YAMASHITA, K. et al. Isolation and species distribution of staphylococci from animal and human skin. $J$. Vet. Med. Sci., v.64, p.245-250, 2002.

NAKANO, M. [Changes of bacterial flora on inbred mouse strains using experimental dental caries model]. Tsurumi Shigaku, v.15, p.235-247, 1989.

QUINN, P.J.; CARTER, M.E.; MARKEY, B.K.; CARTER, G.R. Clinical veterinary microbiology. New York: Wolfe Publishing, 1994. 648p.

STEPANOVIC, S.; VUKOVIC, D.; SAVIC, B.; SVABIC-VLAHOVIC., M. Staphylococcus sciuri: recommendation for simple identification. New Microbiol., v.23, p.201-205, 2000.

TRUDEL, L.; ST-AMAND, L.; BAREIL, M. et at. Bacteriology of the oral cavity of BALB/c mice. Can. J. Microbiol., v.32, p.673-678, 1986.

WAGGIE, K.; KAGIYAMA, N.; ALLEN, A.M.; NOMURA, T. Manual of microbiologic monitoring of laboratory animals. Washington: National Institutes of Health Publication, 1994, 226p.

WALLET, F.; STUIT, L.; BOULANGER, E. et al. Peritonitis due to Staphylococcus sciuri in a patient on continuous ambulatory peritoneal dialysis. Scand. J. Infect. Dis., v.32, p.697-698, 2000. 